\title{
NO MOVIMENTO DAS JORNADAS DE UMA FOLIA DE REIS
}

Recebido em: $28 / 12 / 2020$

Aprovado em: 05/02/2021

Licença:@®) (®)

Sônia Cristina de Assis ${ }^{1}$

Universidade do Estado de Minas Gerais (UEMG)

Belo Horizonte - MG - Brasil

RESUMO: Desdobramento de uma etnografia realizada no contexto da Irmandade Folia de Reis São Francisco de Assis, na cidade de Carmo do Cajuru/MG/Brasil, o artigo aborda a prática festiva, a dança, o canto e os ritos em meio a um trabalho de maturação e associação do que é vivido, daquilo que habilita as pessoas ao desenvolvimento das habilidades. Uma prática social de histórias de envolvimentos e experiências vividas, integrada num sistema sociocosmológico e organizada por uma coletividade heterogênea. No contexto dessa prática apresento os Dourados dos Palhaços e o acordeon promovendo diálogos, mediando as relações e se destacando como potência relacional dentro da performance musical. A antropologia, a etnomusicologia e o lazer tornaram-se, metodologicamente, o caminho para análise desta festa, buscando envolver a relação de elementos como a sonoridade, os cantos e os instrumentos, as danças e os sentimentos.

PALAVRAS-CHAVE: Festa. Música. Atividades de Lazer. Dança.

\section{IN THE MOVEMENT OF THE JOURNEYS OF A FOLIA DE REIS}

ABSTRACT: The unfolding of na ethnography carried out in the context of the 'Irmandade Folia de Reis São Francisco de Assis', in the city of Carmo do Cajuru/MG/Brazil, the article addresses the festive practice, the dance, singing, and rites in the midst of a work and association of what is lived, of what enables people to develop skills. A social practice of stories of involvement and lived experiences, integrated into a socio-cosmological system and organized by a heterogeneous collectivity. In the context of this practice, I present the 'Dourados dos Palhaços e o acordeon' promoting dialogue, mediating relationships, and standing out as a relational Power with in the musical performance. The anthropology, ethnomusicology, and

\footnotetext{
${ }^{1}$ Realizou Doutorado e pós-doutorado em Estudos do Lazer na Universidade Federal de Minas Gerais (UFMG). Mestrado em Educação, Cultura e Organizações Sociais - Universidade do Estado de Minas Gerais (UEMG). Especialização pela Escola de Música da UFMG. Licenciada em Educação Artística com Habilitação com Música pela Escola de Música da UEMG. Integrante do Núcleo de Estudos sobre Aprendizagem na Prática Social (NAPrática) da EEFFTO/COLTEC/UFMG/CNPq.
}

licere, Belo Horizonte, v.24, n.1, mar/2021. DOI: https://doi.org/10.35699/2447-6218.2021.29536195 
leisure became methodologically, the path to analyze this feast, seeking to involve the relationship of elements such as sound, the songs and instruments, dances and feelings.

KEYWORDS: Festivity. Music. Leisure Activities. Dance.

\begin{abstract}
Abertura
A primeira vez que chego à residência de Seu Nego, em novembro de 2013, estão comigo meu filho e meu companheiro. As famílias são apresentadas e de certa maneira são firmados os laços de confiança. Vários encontros ocorreram na casa de Seu Nego e Dona Ana, dois anfitriões queridos que me envolveram nas riquezas de suas histórias e experiências sobre modos de ser e viver neste mundo. Dona Ana, sempre por perto, me chamava para contar suas histórias no tempo que brincava na Folia de Reis, contribuindo enormemente para a pesquisa de campo. Seu $\mathrm{Nego}^{2}$, mestre da cultura popular, reconhecido pela desenvoltura e prática de construir instrumentos percussivos, foi quem me recebeu na oficina, mostrou-me suas caixas e narrou quando se deu o primeiro contato com elas. Pela habilidade de artesão, é responsável pelo zelo dos instrumentos da Folia de Reis São Francisco de Assis. Além de cuidar dos instrumentos o artesão fabrica o Dourado, a caixa, o reco-reco, o tamborim e a máscara. Aos 88 anos é folião cavaquista da Folia de Reis São Francisco de Assis e tem sua arte de construtor de caixas muito apreciada na cidade de Carmo do Cajuru - MG através de seus belíssimos instrumentos.
\end{abstract}

\footnotetext{
${ }^{2}$ No ano de 2017, um ano após defender minha tese, inscrevo Seu Nego para concorrer a $5^{\circ}$ Edição da Premiação Culturas Populares do Ministério da Cultura. O mestre foi classificado e recebeu o prêmio da Edição Leandro Gomes de Barro. Através desse desdobramento organizamos uma oficina de caixas para Reinado em Carmo do Cajuru, momento que o mestre ensinou aos reinadeiros da região a técnica de confecção de caixas que ele mesmo elaborou durante ao longo da vida.
}

licere, Belo Horizonte, v.24, n.1, mar/2021. 
Estava, então, realizando minha primeira incursão no campo, por meio de uma pesquisa etnográfica ${ }^{3}$. Na primeira etapa da pesquisa, no ano de 2013, confecciono uma caixa Reisado, junto ao artesão Seu Nego. Vivenciei cada processo do modo de confecção da caixa, conheci os materiais que a compõe até chegar na materialidade sonora que percorre as festas de Reinado e Reisado da cidade. Em dezembro de 2014 participo do Encontro de Folias de Reis na cidade de Carmo de Cajuru, posteriormente, participo das jornadas da Folia de Reis nos meses de dezembro de 2014, janeiro e dezembro de 2015 e janeiro de 2016.

Mergulhada na pesquisa acompanhei o percurso, registrando as histórias da Folia de Reis São Francisco de Assis presenteadas por devotos e foliões. Por meio dessas narrativas, gravados em audiovisual, produzi um material baseado na qualidade. A câmera de vídeo e o gravador de áudio tornaram-se parte indissociável do diário de campo $^{4}$. Assim, consegui, sistematicamente, recorrer e entrelaçar imagens e análises, pautando experiências de entendimento sobre a performance musical, as entrevistas, as danças os palhaços e do passo a passo da confecção de uma caixa de Folia de Reis. Revisitar o material de audiovisual permitiu-me perceber nuances às quais, muitas vezes, não seria possível abranger em um caderno de anotação.

Assim inicio meu envolvimento neste contexto de festa e ritual, mas é preciso destacar a pessoa que experimentou comigo cada passo da pesquisa. Refiro-me ao meu companheiro que esteve presente e participativo na confecção da caixa que nos empenhamos a construir juntos com o mestre Seu Nego e na captação de áudio das jornadas da Folia de Reis. Durante três anos seguimos um ritual aos finais de semana

\footnotetext{
3 Música e dança na Festa de Reis em Carmo do Cajuru - MG: uma etnografia construída no envolvimento e no movimento de pessoas, instrumentos e sonoridades. Tese (Doutorado) - Escola de Educação Física, Fisioterapia e Universidade Federal de Minas Gerais, PPGEL/EEFFTO-UFMG, 2016.

${ }^{4}$ Utilizei um gravador portátil Zoom H1 e uma câmara Canon de vídeo HD.
}

licere, Belo Horizonte, v.24, n.1, mar/2021. 
que, na maioria das vezes, constava em sair de casa pela manhã e retornar de madrugada, sendo a parceria, a paciência e a dedicação fundamentais para a conclusão do trabalho. Acredito ser importante destacar os bastidores, as pessoas que fortalecem nossas pesquisas e que na maioria das vezes ocultamos.

Devo destacar, também, que desde o início do trabalho de campo, por meu companheiro estar sempre comigo, foi preciso esclarecer aos foliões que a pesquisa era de minha responsabilidade e compromisso com eles. Esse posicionamento demarcou meu lugar de mulher professora, pesquisadora e mãe, pois era necessário dar atenção ao nosso filho, por meio de contato telefônico, que se encontrava em casa.

Então, fui afetada, primeiramente, pela feitura da caixa, mas não sabia que posteriormente, ela me levaria onde fala ou soa. Chego à festa da Folia de Reis, local que emerge o fazer musical. Nessa festa, em meio ao ritual, há uma devoção expressa em palavras cantadas, danças e sons polifônicos sustentados pelos foliões. Decidida, trilhei esse caminho para compreender a relação das coisas, dos sons, da música e dos cantos que se inter-relacionam com o mundo e com as pessoas. Uma inspiração que perpassa pela maneira que os objetos sonoros, ou instrumentos musicais, operam no ritual da Folia de Reis São Francisco de Assis, adotando que estes deixam de agir somente como instrumentos musicais e passam a ser mediadores.

A Folia de Reis São Francisco de Assis, nessa época, era constituída por homens entre 20 a 83 anos de idade. Sendo dois embaixadores, (quem conduz a Folia), quatro Palhaços, também conhecido como Bastião e que se revezavam em dupla, um bandeireiro e os foliões músicos com seus respectivos instrumentos, sendo: duas caixas, dois reco-recos, três pandeiros, duas violas, dois cavaquinhos, três violões e três acordeons. Nessa Folia de Reis, como em qualquer outra prática social, as relações são inerentes à existência humana e as práticas são construções das histórias de vida. licere, Belo Horizonte, v.24, n.1, mar/2021. 
Discorro com campo do lazer como processos de socialização pelos quais as pessoas passam por toda a sua vida social, compartilhando saberes num movimento ético/estético que os mobilizam de forma coletiva. Nesse sentido, a festa da Folia de Reis não se enquadra como um tempo exclusivo para o lazer, nem acontece de forma isolada das realidades vividas pelos devotos e foliões, pois estes criam conexões duradouras na vida cotidiana para que a cada ano as jornadas aconteçam. Dentro desse campo de relações, o lazer, como continuidade da vida cotidiana, permeia nossa condição humana organizada em caminhos de expressão e partilhas, permeada por relações de poder e hierarquias, que envolve conflitos, elaborações e reelaborações que acontecem em qualquer direção.

Investiguei as habilidades dos foliões que emergem em danças, cantos e ritos, em meio a um trabalho de maturação e associação do que é vivido, daquilo que habilita as pessoas ao desenvolvimento das habilidades ${ }^{5}$. Na performance musical da Folia de Reis São Francisco de Assis ${ }^{6}$, encontrei uma prática conectada com a experiência do sagrado, que envolve mito, ritos e sentidos. Segui esse coletivo de pessoas e seus objetos sonoros, em plena liberdade de movimento, continuidade e descontinuidade, e modos de ação na festa. Por meio da música da Folia de Reis vislumbrei uma sonoridade que atravessava a cidade avisando aos moradores a passagem da Caravana. Ao seguir este fluxo, foi-me permitido entrar nas moradas que os foliões visitavam na madrugada adentro.

\footnotetext{
${ }^{5}$ A Festa da Folia de Reis São Francisco de Assis é entendida como uma prática que têm por excelência o ritual. Na atuação do grupo percebemos a existência de uma conectividade entre sagrado, músicos e instrumentos, que nesse caso é o que possibilita torná-los foliões e devotos, ou seja, uma experiência alcançada pela prática de engajamento na Folia.

${ }^{6}$ Nesta festa comemora-se o nascimento do Menino Jesus, sendo as ruas da cidade de Carmo do Cajuru MG/Brasil o lugar dos encontros e das jornadas, entrelaçadas por uma rica experiência tanto musical quanto religiosa. É denominado de jornada, ou viagem, as visitas que a Folia de Reis faz as moradias que irá visitar.
}

Licere, Belo Horizonte, v.24, n.1, mar/2021. 
O foco deste ensaio privilegiará esses movimentos que fluem da presença festiva e da mediação dos objetos sonoros entre cantos e danças. Reforçando, o artigo é um desdobramento de um estudo etnográfico realizado no contexto da Festa da Irmandade Folia de Reis São Francisco de Assis, na cidade de Carmo do Cajuru, MG, entre os anos de 2013 a 2016. Proponho então, nessa inter-relação, um diálogo que compreende uma observação holística sobre coisas, pessoas e mundo. Assim, o olhar minucioso na Folia de Reis São Francisco de Assis retratará uma descrição etnográfica junto a uma análise da movimentação dentro do ritual da festa. Um diálogo pautado entre os campos do Lazer, da Música e da Antropologia destacando a centralidade e a importância dos objetos e dos instrumentos musicais. Neste artigo abordarei a atuação de dois instrumentos, o acordeon de oito baixos e Dourado no momento que eles agem como mediadores. $\mathrm{O}$ acordeon com a função de mediar a performance musical dos foliões e o Dourado de mediar a dança dos palhaços, ora produzindo gestos e ora colocando a Folia de Reis em movimento pelas ruas da cidade de Carmo do Cajuru.

\section{Seguir a Jornada}

O ritual da festa da Folia de Reis São Francisco de Assis é elaborado e reelaborado por diversas gerações. Um momento de viver o passado distante, trazendo-o para o presente, narrando histórias deste mundo em dimensões visíveis e invisíveis. É por meio dos ritos, que os foliões se conectam com o divino e expressam sua realidade com o cotidiano. Sabendo de sua potência, um dos ritos fundamentais do Reisado é não sair em jornadas sem antes rezar cantando. Georges Balandier (1997) nos diz que o rito age nos seres humanos, movimentando corpo e espírito pela união de meios que conjuga música, canto, dança e gesto. Presenciei nos ritos da Folia de Reis São Francisco de Assis todas estas conjunções expressivas. 
Seguir a jornada da Folia de Reis São Francisco de Assis possibilitou captar a comunicação entre pessoas e instrumentos, sendo provocada a entender a relação entre os instrumentos sonoros, o canto e a dança na performance musical. Nessa trajetória, utilizei o entendimento que Tim Ingold (2015) emprega para a palavra movimento. Em vez de uma observação em um ambiente rígido, como se nele tudo já estivesse definido, ele propõe caminhar acompanhado as coisas nos processos, observando as relações entre pessoas e coisas no ambiente, em movimento, descrevendo um caminho (INGOLD, 2015, p. 37). Associo a este entendimento os estudos etnomusicológicos ${ }^{7}$, em que pessoas e objetos de análise são a combinação do tocador e do som produzidos em conjunto com os significados que estão ligados com o evento na sua totalidade.

Em etnomusicologia encontraremos a combinação dos estudos organológicos, antropológicos e musicológicos que inclui uma análise da inter-relação entre o objeto material, pessoa, contexto e música. O estudo aborda o lugar que ocupam esses objetos dentro das práticas de natureza festiva e ritualística, de toda e qualquer forma de vida social e cultural. Sendo assim, sobre as coisas, sabendo que não são simples objetos neutros para nossa contemplação, como descreve Merleau-Ponty (2015), elas evocam e simbolizam certa conduta. "Nessa relação íntima estamos investidos de coisas que falam sobre nós, como também, estão as coisas de pessoas" (MERLEAU-PONTY, 2004, p. 23-24). Ou seja, é necessário compreender que na Folia de Reis São Francisco de Assis as coisas sonoras, que operam nesse ritual, não agem somente como instrumentos musicais, pois os objetos permeiam as relações produzindo sentido.

Do mesmo modo, o lazer se faz presente quando o entendemos como movimento que emerge nas relações históricas e sociais, transitando no corpo dos

\footnotetext{
${ }^{7}$ O termo etnomusicologia é também conhecido como antropologia da música (MERRIAM, 1964) ou mais propriamente etnografia da música (SEEGER, 2008) sendo a ciência que objetiva o estudo da música em seu contexto cultural ou o estudo da música como cultura.
}

Licere, Belo Horizonte, v.24, n.1, mar/2021. 
foliões em diálogo com a música, os sons e os instrumentos. Nas festas ou na vida cotidiana, o lazer não se separa do ritual festivo das jornadas da Folia de Reis, na confecção dos instrumentos ou indumentárias dos foliões. Desta forma, dialogo com o Lazer a partir das experiências vividas de pessoas que dão vida a jornada dos Santos Reis, seja folião ou devoto, que promovem e participam de cada encontro. Como coloca Gomes e Elizalde (2012)

[...] entendemos que a necessidade de lazer vincula-se como fruição de incontáveis práticas culturais constituídas socialmente. Assim, a necessidade de lazer pode ser satisfeita de múltiplas formas, segundo valores, crenças e interesses dos sujeitos, grupos e instituições em cada contexto histórico, social e cultural (GOMES e ELIZALDE, 2012, p.82).

Lazer e Reisado se fortalecem nas experiências vivas e dinâmicas nos territórios brasileiros entrelaçando significados e sentidos. A Folia de Reis São Francisco de Assis é uma organização solidária, mobilizada pela musicalidade e fé, que possibilita folião ou devoto cumprir uma promessa e agradecer pela cura de alguma doença. Harmonizando compaixão e crença em torno daquele necessitado, a Folia de Reis é uma prática que faz emergir sentimentos comuns, possibilitando um fazer coletivo, sensível e ético. Parafraseando Marilyn Strathern (2014, p. 239), "as relações são intrínsecas e não extrínsecas à existência humana”, pois através delas compreendemos como e porque as coisas acontecem e a melhor maneira de percebermos o mundo é colocando as coisas em relação. Pelo toque das caixas, pelos acordes lançados no ambiente, junto a cantoria, a Folia Reis São Francisco de Assis deixa seu rastro sonoro e a paisagem da rua se transforma. Segui essa movimentação no tempo e no espaço dos fluxos musicais. 
Sob esta perspectiva, Ingold (2003) propõe outras associações nomeando o termo socialidade ${ }^{8}$, pois as relações estão envolvidas de pessoas em suas práticas de envolvimento contínuo com o mundo. A escolha do termo socialidade se faz pertinente quando o desejo é jogar luz no campo das relações, atrelando aos estudos do lazer, dentro do campo da coletividade de humanos e não humanos, de entrosamentos práticos entre pessoas, ambiente e suas materialidades. Entendendo que o social não está contido somente de seres humanos. Da mesma maneira, lanço um olhar para as práticas em que a corporalidade se torna marcante nas jornadas da Folia de Reis São Francisco de Assis, no momento em que as danças são realizadas pelos Palhaços em diálogo com a materialidade sonora do Dourado. Nesse sentido, o lazer está imbricado de experiências e aprendizagens como sustenta Luce; Debortoli e Gomes (2010).

Propomos, nesse sentido, pensar as práticas de lazer como aprendizagens de um modo diverso de ser-no-mundo, de um fazer-saber, como possível relação de uma experiência-na-prática grafada na memória dos movimentos, gestos, danças, dramatizações, ritmo e cantos de seus corpos performáticos em sua relação de engajamento no mundo, na 'extraordinariedade' de sua prática cotidiana (LUCE; DEBORTOLI; GOMES, 2010, p.21)

Os anos dedicados às pesquisas sobre o Reisado e o Reinado possibilitou-me entender o lazer pelo viés relacional, ou seja, nas relações que motivam as pessoas, e suas inspirações, a se expressarem e a fazerem arte, intrínsecas de suas realidades históricas e práticas em seus contextos múltiplos.

\section{O Acordeon}

Participar das jornadas exigiu uma dinâmica inesperada, como sair de Belo Horizonte no meio da tarde e percorrer uma hora e meia de estrada para consegui

\footnotetext{
${ }^{8}$ Socialidade é entendida como um campo imanente de relações que diz respeito a humanos e nãohumanos em contextos de entrosamentos práticos.
}

licere, Belo Horizonte, v.24, n.1, mar/2021. 
encontrar os foliões na abertura das jornadas. A primeira jornada que participo com a Folia de Reis São Francisco de Assis aconteceu em 03 de janeiro de 2015, como descrevo abaixo.

Diário de Campo: Em Belo Horizonte, no dia 03 de janeiro de 2015, por volta das 14:00 horas, recebo uma mensagem do filho do Seu Nego, pelo whatsapp. Na mensagem constava "Sônia, a Folia vai sair hoje às 18:00 horas". Seria minha primeira jornada. Depois da notícia foi um alvoroço atrás de equipamentos de filmagem, gravador de áudio, cadernos, bolsas e tudo que fosse necessário para a chegar na cidade e acompanhar a jornada... a expectativa para vê-la na rua crescia... Até então, tinha participado da performance do grupo no "Encontro de Folias de Reis" no dia 07 de dezembro de 2014.

Chego em Carmo do Cajuru e presencio a sonoridade da Folia de Reis ganhar a rua. Com seus passos lentos, o grupo se movimenta até ao portão de uma casa para iniciar a cantoria. As pessoas interessadas em ver a Folia de Reis se acomodam nos passeios com cadeiras, bancos improvisados ou aguardam, em pé na entrada da casa. A paisagem da rua se modifica, instantaneamente, com a passagem do grupo de foliões. As vestimentas brancas, o andar musicado, o colorido das vestes dos Palhaços, as pessoas aguardando nas calçadas, tudo compõe a paisagem. Agraciado pela vizinha com dois reais, um senhor de idade, usando um rosário ${ }^{9}$ cruzado ao peito, aguardava o embaixador finalizar a embaixada. ${ }^{10}$ Todo reinadeiro tem seu rosário. Os embaixadores me confirmam que o senhor, de quase 100 anos, era um capitão do Reinado da cidade e este dia foi o último encontro do capitão com a Caravana. O Reisado, como também o Reinado, são práticas musicais que emergem de um reviver dos ethos africano.

Antes de o embaixador iniciar o canto para o Senhor Capitão, o acordeon de oito baixos fez uma harmonia indicando aos foliões que embaixada iniciaria. Em seguida,

\footnotetext{
${ }^{9}$ Consta como sendo o símbolo maior dos devotos de Nossa Senhora. O rosário contém quinze mistérios, que é a junção de três terços - os gozosos, os dolorosos e os gloriosos - cada um possui cinco mistérios. Todo congadeiro o usa em torno do corpo como proteção (LUCAS, 2002).

${ }^{10}$ Embaixadas são as narrativas, canto do embaixador, que associam a viagem dos Reis do Oriente ou o nascimento do Menino Deus.
}

Licere, Belo Horizonte, v.24, n.1, mar/2021. 
todos os instrumentos, inclusive o acordeon, tocaram simultaneamente criando uma base harmônica para o embaixador cantar a primeira estrofe.

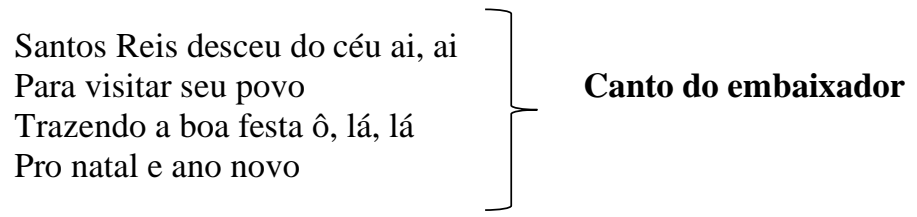

Logo após o canto do embaixador os foliões, juntos, cantaram o refrão. Ao terminarem o canto de refrão o acordeon de oito baixos sustentou um acorde de tônica, momento que o coro de foliões realizaram uma sobreposição de vozes, denominadas por eles de $1^{\mathrm{a}}$ voz, $2^{\mathrm{a}}$ voz, contralto e retinta. Essa sobreposição de vozes acontece sempre no fechamento do canto do coro de foliões com o uso de interjeições como (oi, ai) e é o que caracteriza o canto da Folia de Reis.

Santo Reis desceu do céu ai, ai Para visitar seu povo Trazendo a boa festa ô, lá, lá Pro natal e ano novo ai, ai

\section{Refrão}

Os ciclos de estrofe e refrão foram repetidos e o acordeon protagonizou a cena dando entrada para o embaixador cantar outro verso e o coro de foliões, juntos, responder com o refrão. Destaco nesse momento a sutiliza do tocador de acordeon ao mediar com seu instrumento o momento exato para a Folia de Reis iniciar ou finalizar o canto. Trabalhar com o acordeon de oito baixos não é uma tarefa fácil, pois ao abrir o fole o instrumento soa uma nota e ao fechar soa outra. Por outro lado, sem a sintonia e cumplicidade do grupo não seria possível uma boa execução musical durante todo o percurso. De fato, aconteceria o que a Folia de Reis chama de "enxurrada". Sendo o desencontro rítmico e melódico dos instrumentos com o canto no momento da 
performance. Para que isso não aconteça o acordeon de oito baixos é fundamental, é ele que mantém a afinação do canto do embaixador quando inicia uma embaixada dando a marcação de entrada e término. Por isso um embaixador nunca inicia uma embaixada sem antes ouvir o acorde da "cabecinha de égua", outro nome dado ao acordeon de oito baixos. Assim, o acordeon de oito baixos vai mediando a prática musical da Folia de Reis São Francisco de Assis entre pergunta e resposta, ou seja, entre o canto do embaixador e o coro dos foliões.

Outro ponto importante de ressaltar, sobre o papel de mediação do acordeon de oito baixos, diz respeito a organização espacial da Folia de Reis. Presenciei uma organização mais orgânica, ou seja, os foliões se movimentam livremente ficando no entorno dos embaixadores e do acordeon. Percebi o quanto o grupo trabalha com uma escuta ativa, atentos ao som do acordeon de oito baixos, para assim promover uma boa execução musical. Os foliões podem estar tocando seu instrumento de costas ou de lado dos embaixadores, sem nenhum prejuízo para a performance, pois a escuta é bem desenvolvida e conectada com tudo que se passa no ambiente. Uma escuta acurada que revela a habilidade musical garantindo a continuidade da tradição. Um modo de organização e participação que promove a prática e fortalece o grupo musicalmente. Nunca uma toada é a mesma, portanto a descrição que faço diz de uma dada experiência ou de um fluxo musical em que o canto do embaixador é alternado pela resposta do coro dos foliões. Nessa relação, o acordeon ganha funções específicas de mediador para que as embaixadas aconteçam, conduzindo o fazer musical, ao dar entradas ou marcações ao canto.

Do mesmo modo, a participação do devoto não se dá passivamente. Neste encontro, o senhor reinadeiro participava da performance de maneira emocionante e verdadeira. Durante a exposição dos versos sagrados aconteceu uma comunhão entre licere, Belo Horizonte, v.24, n.1, mar/2021. 
devoto e folião, uma comunicação gestual de bênçãos e uma expressividade única do momento vivido.

Naquele dia, a interação entre folião e devoto foi exercida pelos papéis que cada um assume neste coletivo, possibilitando uma organização de experiência da vida social. Cantar para uma pessoa permite compreender esta pessoa como participante da Folia de Reis, seja por meio da integração de gestos ou pelos sons vocais que são inseridos no ato da performance, permeados de sentidos e sensibilidade. Pelo olhar convidativo, pelo toque de mãos, abraços, pelos sons, pelas frases cantadas e criadas, pela bênção de agradecimento, tudo isso diz sobre o que é ser pessoa folião ou pessoa devota. No fazer musical da Folia as pessoas pronunciam suas experiências arranjadas no mundo que as rodeiam.



Versos cantado pelo Embaixador para o senhor capitão de Reinado

Santo rei desceu do céu ai, ai Para visitar seu povo

Refrão Trazendo a boa festa ô lá, lá Pro natal e ano novo

O meu nobre companheiro 
Pra você eu canto agora

Vim aqui te visitar ô lá, lá

Com o mandado de Nossa Senhora

O destino guiando o bem

Vem fazer nossa união

Santo Reis lhe dá um abraço ô lá, lá

Também um aperto de mão

O meu nobre capitão

Filho da Virgem Maria

Você fica aí com Deus ô lá, lá

Com filho da Virgem Maria

Abrindo os braços, parecendo querer abraçar a Folia de Reis, o Senhor Capitão do Reinado com sua voz rouca, afinada e intensa, emitiu um som possante junto ao coro dos foliões. Depois solicitou um contato corporal, um abraço e um aperto de mãos para selar o encontro em nome dos Santos Reis do Oriente. Experiente e conhecedor de saberes cosmológicos, o Senhor Capitão retribuiu os versos cantados pelo embaixador o benzendo. Este ato entrelaçou as energias dos irmãos do Reinado e do Reisado em uma trama de fé, respeito e sabedoria.

As jornadas da Folia de Reis São Francisco de Assis são arranjadas por experiências diversas que não se encaixam, portanto, a uma fragmentação da vida e ao momento sugestivo de "bem-estar" de "entretenimento", pois são obrigações que não separam o trabalho do contexto festivo. As experiências contidas na Folia de Reis perpassam por um entendimento de práticas arranjadas e as jornadas promovem uma socialidade entre foliões e devotos conectada com a experiência do sagrado. No movimento das jornadas - esboçadas pela música, pelos objetos sonoros, pelas pessoas e os cantos - todas essas especificidades se constituem em um sistema de relações e habilidades em um território de sentido. 
Figura 1: Canto para saudar devotos.

\section{Canto para saudar devotos}

Embaixada: Geraldo Ferreira de Araújo (Assobio).

Folia de Reis São Francisco de Assis $\cdot=40$
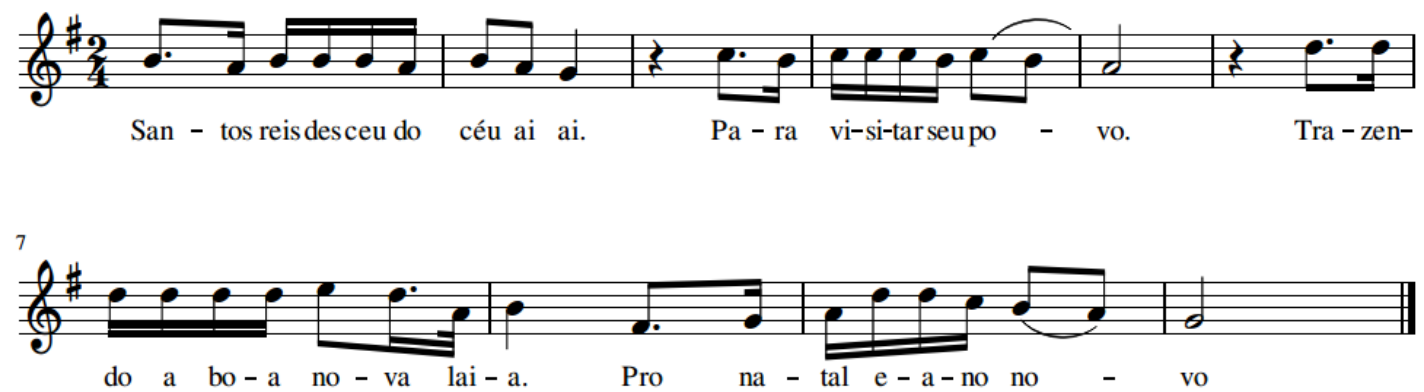

Há diferença em cantar na rua para uma pessoa e cantar diante do presépio. Segundo os embaixadores, os cantos na rua surgem pela criatividade ou improviso e no presépio por escrito (são os versos anotados em um caderninho). No entanto, todo o verso direcionado ao devoto ou diante do presépio requer dos embaixadores um conhecimento profundo sobre os fundamentos que envolvem os rituais da Folia de Reis. Esta experiência é que possibilita colocar em prática o processo criativo de improvisar versos. Os versos cantados que surgem de improviso/criatividade, na maioria das vezes, tocam as pessoas por serem versos sinceros e acolhedores. Cantar para uma pessoa na rua desencadeia emoções, traz lembranças de seus antepassados. Diante do presépio, no entanto, os versos cantados são diferentes, pois para saudá-lo os embaixadores precisam ter o conhecimento dos versos que são memorizados. Esses retratam a passagem dos 
Reis Magos no deserto ao encontro do Menino Jesus. Somente os embaixadores experientes têm acesso a esses versos e por isso somente eles podem saudar o presépio.

Primeiro Embaixador: A música do presépio é uma música que você está concentrado em frente ao Menino Jesus, né? Agora, as músicas na rua, você está cantando concentrado... assim... você está com aquele objetivo e aquela devoção. Só que as músicas são diferentes. Por exemplo, você está cantando para uma pessoa na rua agradecendo a esmola ou só cantando para aquela pessoa. Você está cantando ali com criatividade e memória, né? No presépio não. Você está cantando por escrito.

Segundo Embaixador: Forte... falar a verdade para você, tem hora que a gente se emociona tanto. Tem hora que a gente canta e depois que acaba de cantar, vai raciocinar a música, a emoção bate muito forte. Bate forte de mexer com a gente. A gente lembra de uma pessoa da família que já se foi, partiu. Tem hora que a gente se emociona tanto que os olhos chegam a encher d'água de tanta emoção. Emoção não é de cantar, é da gente alcançar aquele objetivo. Às vezes você dá uma esmola e põe na bandeira. Não tem como eu passar para você como é que a gente está cantando para tirar aquela esmola da bandeira. Mas, a gente tem aquela emoção de cantar para a sua pessoa, você se sente emocionada, vem a chorar por aquele verso que a gente fez te agradecendo. O que você deu para os Três Reis do Oriente, para São Sebastião. Você está entendendo?

Na performance da Folia de Reis São Francisco de Assis cada ser humano é afetado e envolvido de maneiras diferentes, uns pela sonoridade ou emoções, outros pelo movimento ou cores. Sentindo, inspirando e observando o ambiente que os rodeiam. Somos afetados pelas vias sensoriais, quando inseridos no coletivo, para isto é necessário "expormos", “expor nosso corpo". "Afirmar a paisagem é garantir que, lá fora, as coisas acontecem sob suas formas mais concretas de luz, temperatura, qualidade do ar, odores” (BESSE, 2014, p. 247). A Folia de Reis São Francisco de Assis se lança nas ruas compondo uma paisagem estruturada de danças, cantos e ritos. A sonoridade participa, ativamente, da construção social do nosso ambiente espacial e temporal. Assim, se quisermos sentir os espaços pela escuta, ou experimentar o espaço sonoramente, melhor concentrarmos no momento da performance. Pois, é no fazer 
musical das práticas tradicionais que encontramos experiências múltiplas e a maneira como ela é vivida.

No trabalho de pesquisa de campo produzi um extenso material de audiovisual e fotográfico que contribuíram, imensamente, no processo de observação e análise ${ }^{11}$. Revisitar o material permitiu "voltar" ao campo e me deliciar com tudo o que foi vivido, rememorei as relações que entrelaçaram histórias, pessoas e objetos. Nesse mergulho pós-campo, junto às minhas experiências corpóreas, cada revisitação culminou no aprofundamento e entendimento das relações entre os foliões, os devotos, as caixas, o acordeon, os cavaquinhos, as violas, os violões e os Dourados ${ }^{12}$. De volta ao campo vivo e dinâmico reencontrava os foliões engajados na escuta ativa, vendo e imitando os mais experientes, sentindo e compartilhando emoções mútuas. Os aprendizes dessa prática, sendo eles instrumentistas, cantores ou dançarinos desenvolvem suas habilidades, participando, dialogando, observando, escutando e executando a performance da Folia de Reis. Como destaca Ingold (2010), um aprender que acontece por uma redescoberta do conhecimento que não está fora das pessoas (que seria o mesmo de uma transmissão de conhecimento), mas que se desponta pelas habilidades e inserção no ambiente.

[...] Copiar é imitativo, na medida em que ocorre sob orientação [...]

[...] copiar não é fazer transcrição automática de conteúdo mental de uma cabeça para outra, mas é, em vez disso, uma questão de seguir o que as outras pessoas fazem (INGOLD, 2010, p. 21).

\footnotetext{
${ }^{11}$ Para esta pesquisa, os integrantes da Folia de Reis autorizaram fotografar e filmar as jornadas, como também as conversas/entrevista. Os mesmos assinaram, em duas vias iguais, o termo de consentimento livre e esclarecido TCLE, ficando uma cópia com cada integrante e outra cópia com a pesquisadora.

12 O Dourado, instrumento sonoro dos Palhaços, se destaca pela sonoridade e sentido, uma materialidade que carrega funções particulares no desenvolvimento da performance artística dos foliões Palhaços.
}

licere, Belo Horizonte, v.24, n.1, mar/2021. 
Para Ingold (2010), aprender é sinônimo de uma redescoberta orientada que, como tal, envolve imitação e improvisação. Desta maneira, o aprendizado passa pelos processos de redescobrimento dirigidos pela noção do mostrar, do escutar e do sentir. Aprender se torna um processo de aprendizagem que compreende todo um sistema perceptivo do praticante habilidoso e integrado com o ambiente. Na prática musical da Folia de Reis São Francisco de Assis esse aprender perpassa dentro do fazer musical, no âmbito da interação entre os instrumentos e os cantos, sem eliminar as brincadeiras e as danças dos Palhaços. Nas ruas da cidade de Carmo do Cajuru, a partir do dia 25 de dezembro, a Folia de Reis emerge em energia e expressividade musical, dos habilidosos aos principiantes, unidos por fortes vínculos familiares ou de amizades. Neste coletivo, experiências são organizadas dentro de um contexto ritualístico em que cada preparação e acontecimento é um ensaio, pois todos os conhecimentos e saberes são adquiridos participando na prática, em dia de Santos Reis.

Durante o ato de se relacionar, mutuamente, encontrei o compartilhamento de saberes daquilo que é vivido, que de certa forma é aprendido. Musicalmente, quando as pessoas experimentam a capacidade da escuta estruturada elas desenvolvem a habilidade de ouvir e reconhecer padrões sonoros. O fazer musical da Folia de Reis São Francisco de Assis é passível de sentido e de tradição, nele os foliões desenvolvem a percepção, no que diz respeito a uma ordem no âmbito sonoro, que se torna indissociável do movimento corporal. Os cânticos da Folia de Reis São Francisco de Assis, ou seja, a junção de melodia/ritmo/versos é denominada pelos foliões como toada. Nas toadas da Folia de Reis São Francisco de Assis encontramos os versos cantados, integrados aos ritmos das caixas, direcionados aos devotos e ao presépio. 


\section{Os Palhaços}

A performance dos Palhaços, também conhecidos por Bastiões, diz respeito a todo o desenvolvimento das jornadas. A Folia de Reis São Francisco de Assis é composta por dois Palhaços que são os responsáveis em não a deixar presa, parada por muito tempo, no momento em que as pessoas trocam esmolas por cantos e danças. Alguns devotos gostam de tê-la por mais tempo na porta da casa e para prendê-la basta pagar o canto com moedas de pequeno valor. Para os embaixadores, uma pessoa pode segurar a Folia de Reis dando cinco reais em moedas de cinquenta centavos. Este procedimento atrasa a jornada dos foliões que poderiam cantar para outras pessoas. Por isso, os Palhaços precisam ser ágeis e mostrar toda experiência nas brincadeiras. A função dos Palhaços, além de arrecadar esmolas de agradecimento, é promover o desenvolvimento da performance. Enfatizarei os modos de mediações entre o instrumento sonoro do folião Bastião, os cantos e os gestos, destacando os sentidos que emergem das relações que entrelaçam os foliões e o instrumento sonoro denominado Dourado.

A história do Palhaço nas Folias de Reis está associada com o Rei Herodes, o qual tinha a intenção de matar o Menino Jesus. Para isso vestiu uma máscara para que não fosse reconhecido pelos pastores e os Reis do Oriente, porém, ele não encontrou o local em que estava a criança. Os Palhaços da Folia de Reis representam e expressam o Rei Herodes, e sua maldade, não podendo assim comparecer diante de um presépio. Este mito é cantado/narrado e representado pelos foliões na festa da Folia de Reis, quando a história se torna ação, concebido pelo rito que contempla a representação, os cantos e seus personagens.

A máscara que os Bastiões utilizam, também, resguarda a identidade deles, por representarem a perversidade do Rei Herodes, diluindo os sentimentos negativos para 
com os foliões. Assim, no lugar do ódio nasceu o jogo e a brincadeira, que gera o desafio de desmascarar os Palhaços, motivando um processo lúdico de interação entre o devoto e o folião. Ainda hoje os Palhaços se vestem em ambiente fechado e longe de olhares curiosos. Como nos lembra Bakhtin (1999, p.35), a máscara recobre a natureza inesgotável da vida e seus múltiplos rostos. Sem ela os Palhaços, provavelmente, não poderiam exercer o jogo do disfarce e a representação verdadeira do cômico popular Neste contexto de prática social, destacarei a expressão sonora - que expõe uma rica corporalidade de gestos e movimentos - que emerge do diálogo dos Palhaços com o Dourado. Abordarei a potência relacional que este objeto sonoro promove, mais especificamente nas danças. Como interação com o cotidiano da vida da população, a música da Folia de Reis, que flui do encontro dos Palhaços e seus Dourados, coloca pessoas e instrumentos em movimento. Neste caminho, com o sentido de Ingold (2012), coisas e pessoas expressam-se e se revelam em música.

Me aproximei destes foliões pelas danças e gestos para entender a técnica e a arte, no sentido de experiência social. Em cada dança o corpo assimila um conjunto de gestos, ritmos, passos e tempos em um ajuste de intencionalidade, e movimentos carregados de sentido. São processos que constam a pessoa situada, experimentando, crescendo e sustentando uma prática de vida, de atividades e em coletividade (INGOLD, 2010). Uma técnica que se integra na composição de Ser Palhaço, na expressividade dos corpos, em ação, com os Dourados e no movimento dos sons da Folia de Reis.

Quando a Folia de Reis está cantando na rua para as pessoas, os foliões mascarados têm funções diferenciadas dos demais foliões. Eles conduzem o momento promovendo o riso e o jogo da máscara. São os únicos na Folia de Reis que se utilizam de uma vestimenta colorida, promovem as brincadeiras e as danças, encenando um licere, Belo Horizonte, v.24, n.1, mar/2021. 
papel perverso em um momento e, em outro, protegendo devotos e foliões. A atividade destes foliões acontece somente na rua, em um terreiro ou na sala de visita de algum devoto, porém, nunca diante de um presépio. Durante a adoração ao presépio, a presença dos Palhaços é proibida no recinto, e somente, depois dos embaixadores saudarem o presépio eles estão liberados para circularem na casa. Quando o embaixador está cantando para o presépio os Palhaços se posicionam distante do grupo, quase sempre ficam na rua, dançando e brincando com as pessoas.

\section{Os Dourados dos Palhaços}

Os Palhaços saem às ruas vestidos com um macacão florido, um saquinho de pano pendurado na cintura para guardar esmolas, um capacete, uma máscara cobrindo o rosto e o Dourado em mãos. Esse último é um bambu que mede aproximadamente $2 \mathrm{~m}$ de comprimento tendo na extremidade superior tampinhas de metal presas por um fio de arame, que exercem a função de um chocalho. Quando a base inferior do Dourado colide no chão as tampinhas se chocam e o som produzindo é amplificado por todo o bambu. A utilização desse instrumento sonoro é acompanhado pelo movimento corporal do Palhaço, que pode ser um balanço lateral na cadência da música ou um impulso vertical no mesmo lugar. Dessa maneira eles participam da performance musical, ora marcando o tempo forte e ora acompanhando a célula rítmica das caixas e sanfonas. Em entrevista, o embaixador narra sobre os Palhaços e seus Dourados.

Primeiro Embaixador: - Aquilo é os instrumentos deles. Aquilo já foi criado pelo homem. Os Palhaços não tinham instrumentos. É criatividade do homem mesmo, assim, com o Dourado na mão e com as palhaçadas que eles fazem é criado para chamar atenção. Mas eles fazem parte da mesma coisa que nós na folia. O Palhaço tem que ter muita comunicação, nada fecha eles, tudo que você pergunta eles respondem. 
A riqueza do Dourado, nessa prática social, aponta o quanto esse objeto é personificado quando se anuncia junto aos Palhaços. Assim, o Dourado é tão expressivo quanto os dançarinos, quando ambos se complementam ou se amparam mutuamente. É na dança dos Palhaços que encontramos uma riqueza de relações cuja centralidade de sentidos emerge da corporalidade dos sujeitos. Materializada em processos rituais e festivo, essas danças manifestam a partilha e a produção cotidiana de experiências e saberes sociais. Como experiência vivida, ela não tem como objetivo ser uma representação de eventos, ela provém de uma incerteza quando, nesse envolvimento, o objetivo é chamar a atenção das pessoas para o ato expressivo ou para a Folia de Reis. Então, tudo pode acontecer e mudar o fluxo da jornada da Folia de Reis São Francisco de Assis, como a captura dos Dourados dos Palhaços.

Quando os Palhaços não estão executando um pedido de dança o Dourado interage de maneira diferente na Folia de Reis. Como a cena do embaixador cantando para uma pessoa na rua, momento em que os Palhaços seguem o pulso da música batendo seus Dourados no chão em um diálogo de pergunta e respostas. Enquanto um Dourado marca o tempo forte o outro executa uma célula rítmica e vice-versa.

Figura 2: Exemplo de variações rítmicas dos Dourados. Cada linha corresponde a ação de um Dourado.

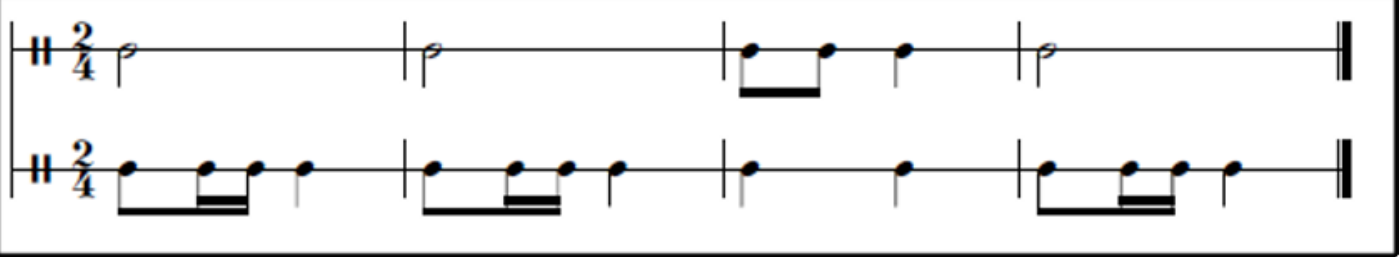




\section{As Danças ${ }^{13}$}

O entendimento de dança que apresentarei delineia movimentos rítmicos expressos no corpo em plena relação com a toada e com o Dourado. A dança dos Palhaços emerge por um entendimento mais intenso que perpassa pela técnica, pela arte e, com um olhar mais aguçado, pela experiência social. Referirei a técnica no sentido tradicional, apoiando em Marcel Mauss (2003 [1934]), ou seja, a técnica existe quando existe tradição. Para Mauss o ato tradicional, ou uma técnica eficaz, não difere do ato mágico, religioso e simbólico, sendo sua consideração importante para nossos estudos. Neste sentido, as danças dos Palhaços são projetadas por um corpo que já assimilou um conjunto de gestos, ritmos, passos e tempos.

Ocupando uma posição diferenciada na Folia de Reis São Francisco de Assis, os Palhaços constroem e elaboram conhecimentos dentro do fazer coletivo, o qual gera significado a cada pedido de dança, firmando funções e organizando a vida social em coletividade. As danças se tornam um forte componente deste contexto musical. Elas me foram reveladas, no momento, que surgiram pessoas que sabiam de sua existência e pagaram com esmolas para os Palhaços dançarem. Caso não haja pedido de dança, os palhaços dançam assim mesmo abraçados aos seus Dourados.

Uma corporalidade que se ajusta numa intencionalidade de movimentos e sentido vividos. São processos que constam de um desenvolvimento da pessoa situada, experimentando, crescendo e sustentando uma prática de vida de atividades e em coletividade. O pedido de dança desafia os dançarinos a improvisarem tanto danças como cânticos. É respondendo cada desafio que eles exibem a arte de ser Palhaço,

\footnotetext{
13 Registro em vídeo das danças realizado pela pesquisadora. Disponível em: https://www.youtube.com/watch?v=dJiISZpMhZA. Acesso em: 26 dez. 2020.
}

Licere, Belo Horizonte, v.24, n.1, mar/2021. 
mediando danças entre as práticas as quais são habilitados. Pelos gestos, os Dourados assumem formas. São personificados quando os dançarinos fazem deles pessoas e dançam com eles. Abaixo, dialogarei com as quatros danças que me foram apresentadas nas jornadas da Folia de Reis São Francisco de Assis.

\section{Dança Cobra Coral}

O sanfoneiro faz a introdução para iniciar uma música/dança. Cada palhaço coloca seu Dourado, paralelamente, no chão, mas em sentido contrário. Depois os dois dançam por cima dos Dourados até que um deles faz, oh, oh, oh, oh. Imediatamente, os dois pegam cada qual seu instrumento e o tiram do chão. Algumas danças são solicitadas pelas pessoas que a Folia de Reis encontra em jornada. Para isso é necessário que elas contribuam com uma pequena quantia em dinheiro, outras ocorrem espontaneamente pelos dançarinos durante a performance da Folia de Reis.

\section{Imagem 2: Acervo Sônia Assis.}

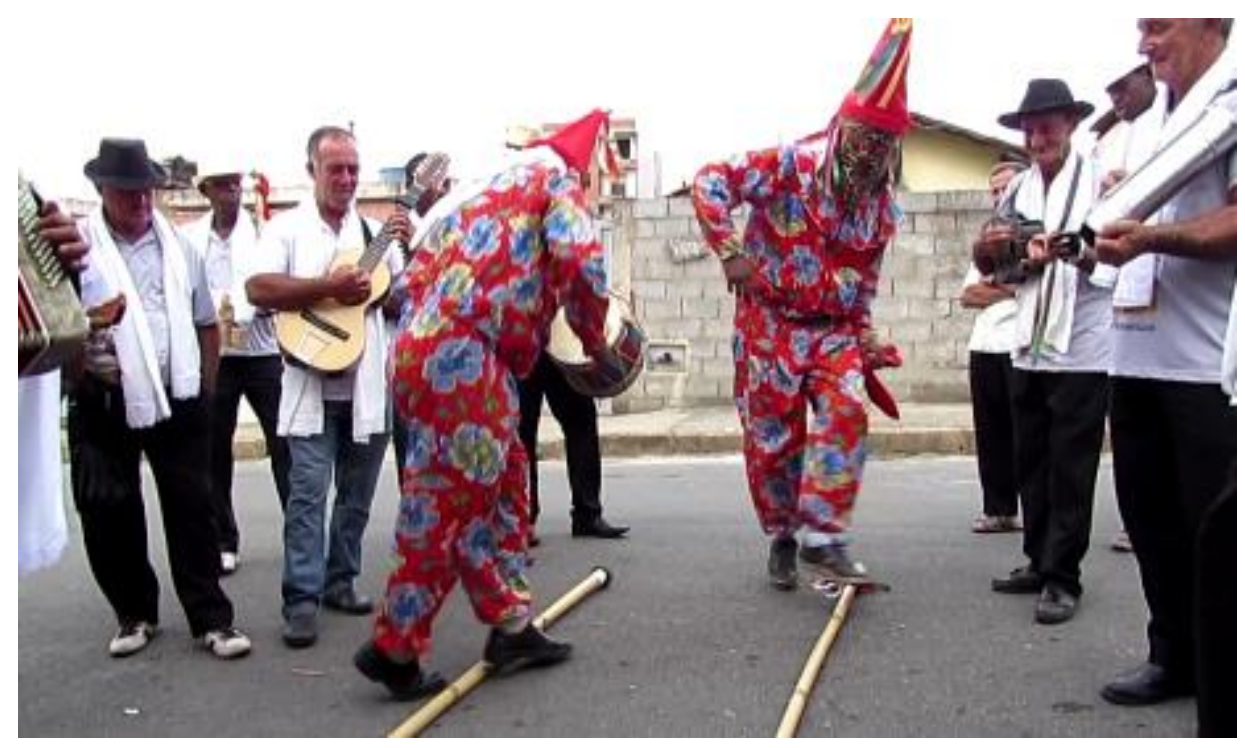

É importante ressaltar que o pedido de dança se torna um momento de vigília para os Palhaços, pois em algumas danças eles deixam seus Dourados no chão, 
momento propício de serem capturados. Nessa ocasião a sanfona e as caixas são os únicos instrumentos que acompanham a dança Cobra Coral. Ela pode ser realizada com um Palhaço dançando por sobre o Dourado ou, em outro momento, com ambos dançando por sobre seus Dourados. Apresentarei a primeira. Essa dança inicia quando um dos Palhaços coloca seu instrumento sonoro no chão e percorre sua extensão saltitando com as pernas cruzadas. O outro Palhaço se posiciona ao lado e, inesperadamente, empurra com seu Dourado o que está no chão. Feito isso, o Palhaço dançarino acaba pisando no Dourado e o desequilíbrio corporal o leva ao chão.

A cena que gera muitas risadas é também uma estratégia, tendo como objetivo encurtar a dança. Ficando o Dourado no chão, sem a devida proteção, um devoto atento pode apanhá-lo e escondê-lo. A devolução acontece somente depois que a Folia de Reis canta por horas para o devoto. A pessoa, ainda de posse do Dourado, pode exigir que os Palhaços dancem, faça agrados em versos, elogios e só depois de satisfeito o devoto devolve o Dourado. São aventuras como essas que fazem da performance dos Palhaços uma improvisação constante. A arte da dança dos Palhaços, o corpo em ação com os Dourados, permanece inseparável à noção de técnica, pois no sentindo amplo do movimento dos corpos e dos sons dos instrumentos inseridos em um ambiente é que possibilita reinventar a dança, os dançarinos e a técnica.

\section{Dança Moinho}

A Dança Moinho acontece enquanto o embaixador está cantando para alguém, ou seja, os Palhaços dançam espontaneamente sem a necessidade de um pedido. Essa dança consta de um gesto o qual representa a união dos dançarinos. Na Dança Moinho os Palhaços se abraçam e dançam com os Dourados cruzados, entre eles, formando um X. Os Dourados ao mesmo tempo em que determinam um limite entre os corpos dos 
Palhaços também os aproximam, um elo de entendimento e de permissão que somente os Bastiões experimentam.

A dança inclui uma elaboração fraterna do gesto, que gera o abraço, aproximando foliões e devotos. Ela descreve, também, as peripécias desses atores por meio da representação cômica, da brincadeira com o corpo e com jogo da máscara. Ocupando uma posição diferenciada na Folia de Reis, os Palhaços ora negam o sagrado e ora o afirma. Assim, eles constroem e elaboram conhecimentos dentro do fazer coletivo, o qual gera significado a cada experiência vivida, firmando funções e organizando a vida social.

Imagem 3: Acervo Sônia Assis.

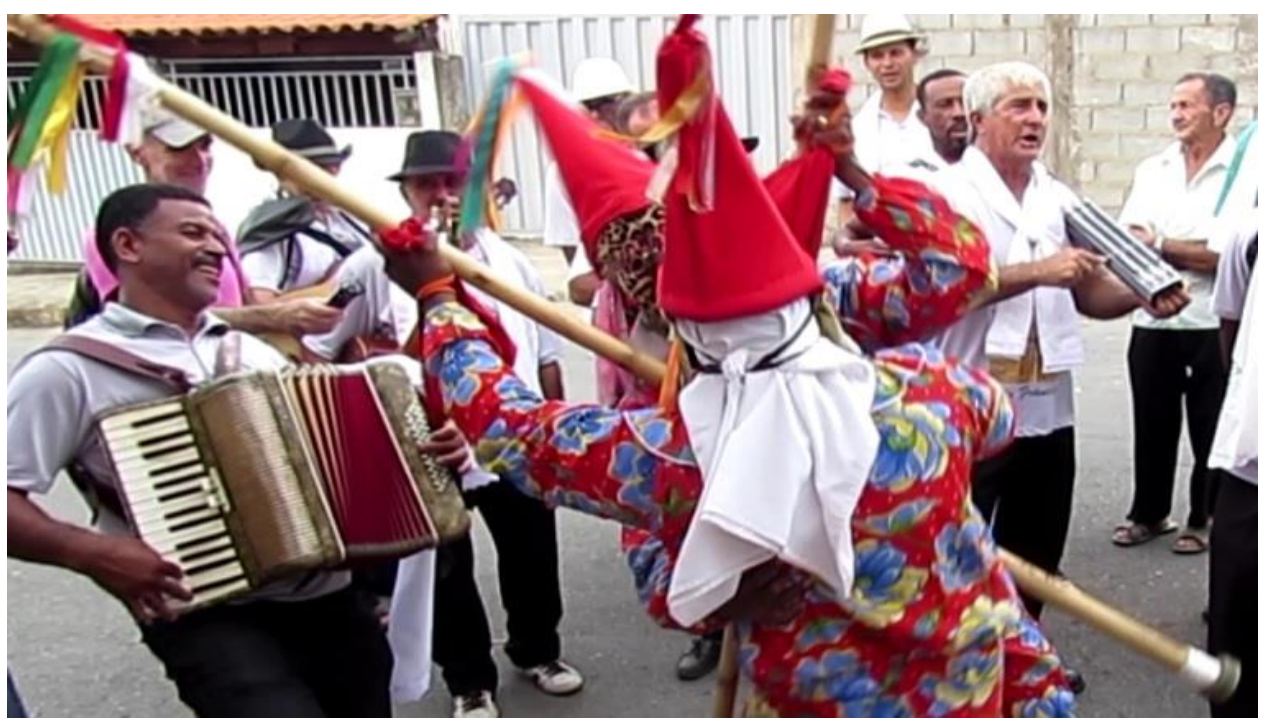

A movimentação é simples. Os Palhaços dançam com seus Dourados como se estivessem dançando com uma pessoa. Aos pouco eles se aproximam até que os 
Dourados se encontrem, e em seguida eles se abraçam com os Dourados entre eles. Com graciosidade, os dançarinos jogam seus corpos para um lado e para o outro acompanhando o andamento da música, e tudo se torna um, humanos e não humanos.

Enquanto os foliões cantam e tocam para algum devoto dos Reis do Oriente, os Palhaços dançam unidos aos instrumentos. Por fim, eles se soltam indo em direções opostas fazendo algazarra. A Dança Moinho é realizada num curto período de tempo, depois, separadamente, cada Palhaço dança, sozinho, com seu Dourado. Nesse gesto os Dourados assumem outra forma na dança, eles são personificados, passando a ser uma pessoa. Quando os objetos sonoros se tornam pessoas, no sentido enfatizado por Strathern (2006, p. 267), são as danças que, por sua vez, revelam o Ser Palhaço, dentro de práticas constituídas de relações coletivas e cotidianas.

\section{Dança Moçambique}

Essa dança tem relação com o Terno de Moçambique do Reinado Mineiro e ocorre pelo pedido de um devoto. Essa imbricação de práticas é comum em Minas Gerais, pois muitos foliões são integrantes ativos do Reinado de Nossa Senhora do Rosário e das Folias de Reis. Nessa dança outros significados são articulados ao corpo dos Palhaços dançarinos, pois o Reinado retrata os tempos de escravidão do povo negro no Brasil. De imediato há uma modificação na batida das caixas que passam a repicar. Os corpos dos Palhaços dançantes são modulados de maneira que seus ombros se curvam para o chão e seus joelhos são ligeiramente flexionados, buscando assim o moçambiqueiro do Reinado. Pela corporalidade dos Palhaços, conectada ao som do acordeon e das caixas, as histórias dos antepassados é apresentada nos pés dançantes 
que tocam o chão, como se as gungas ${ }^{14}$ estivessem amarradas em seus tornozelos. No canto forte e expressivo eles mergulham num imaginário de experiências vividas ao exibirem um enriquecimento de saberes e vivências.

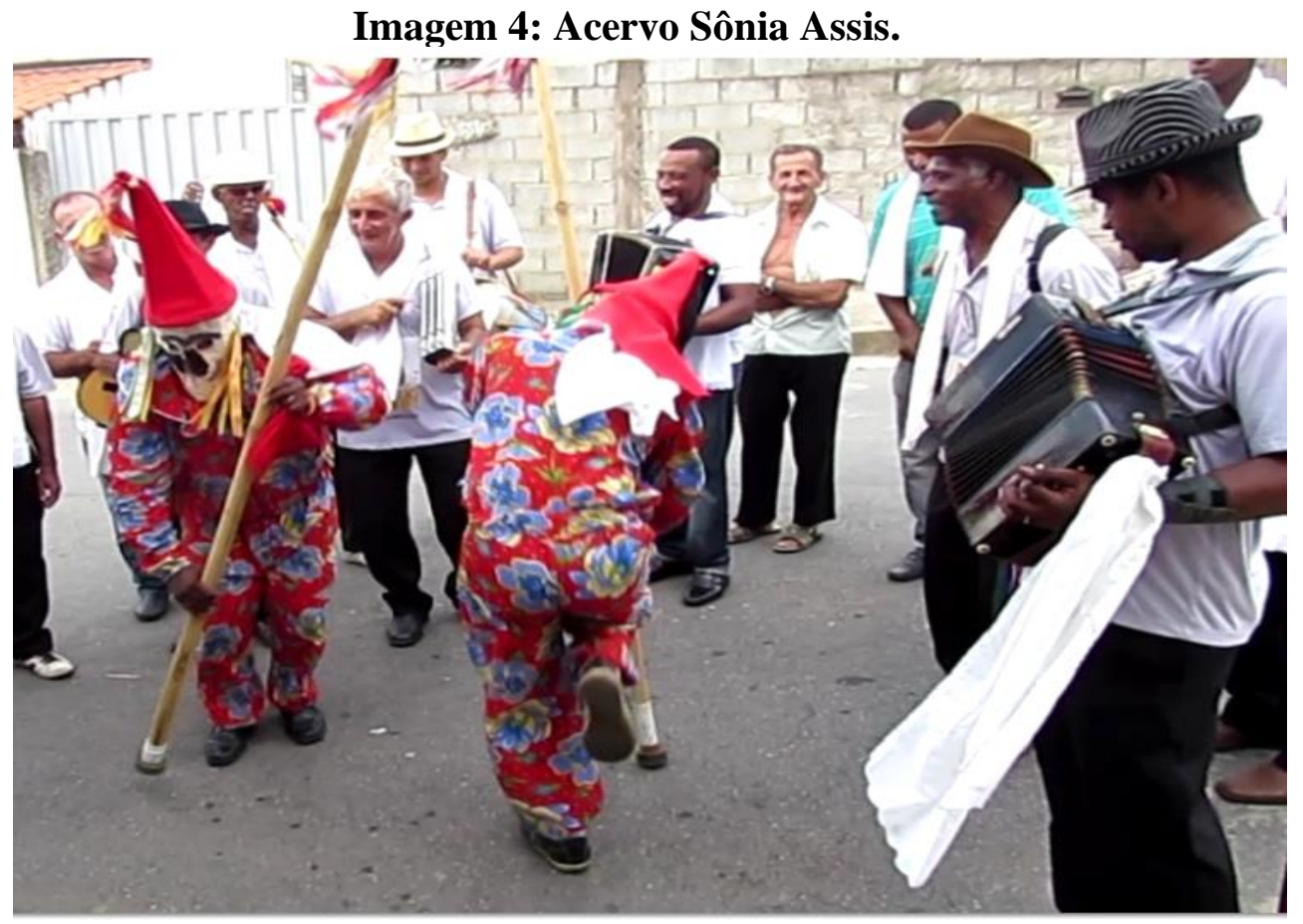

\footnotetext{
${ }^{14}$ As gungas, da Guarda de Moçambique Nossa Senhora do Rosário, são cilindros fabricados com folhas de zinco e presos em uma tira de couro. Para que fique firme nas pernas do dançarino usa-se uma espuma grossa, esta é anexada à tira de couro. Dentro dos cilindros usa-se chumbinho e o número de cilindros, em cada pé, podem variar de seis a oito.
}

licere, Belo Horizonte, v.24, n.1, mar/2021. 
A corporalidade dos Palhaços da Folia de Reis São Francisco de Assis é expressão e experiência, que recria, reconta, reconstrói e remodela gestos em meio às danças na performance musical. Por meio destas experiências vividas os corpos dos Palhaços promovem ações coordenadas em movimentos rítmicos, junto ao seu objeto sonoro, o Dourado, carregando funções particulares para assim promover a performance artística desses foliões. Uma corporalidade que expressa histórias de resistência. Presenciei seus pés dançantes tocarem o chão como se gungas estivessem amarradas em seus tornozelos. Segundo o mestre capitão do Reinado de Nossa Senhora do Rosário de Justinópolis-MG as gungas lembram os sinos que os senhores de escravos colocavam nos escravos, tendo como propósito achar o "escravo fujão". Hoje, elas representam o tempo de sofrimento dos escravos, um tempo cantado e contado em seus pontos ${ }^{15}$. Depois de incorporarem o moçambiqueiro os dançarinos repicam seus pés no chão acompanhando as caixas e cantando a frase "Chorou, chorou o sabiá". O canto foi repetido duas vezes pelos palhaços, em seguida os foliões responderam repetindo a mesma frase.

Figura 3: Canto dos Palhaços na dança do Moçambique.

\section{Chorô o sabiá}

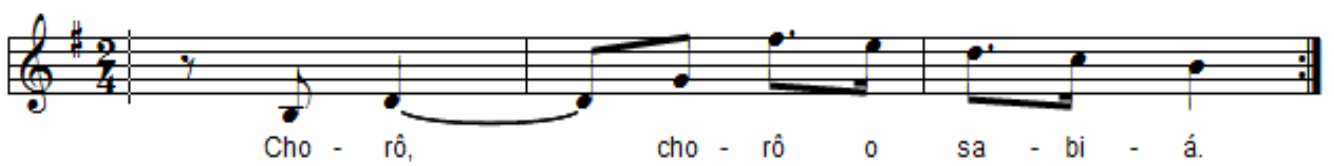

\section{Dança da Jaca}

\footnotetext{
15 Relato do Senhor Dirceu, capitão da Irmandade de Nossa Senhora do Rosário de Justinópolis. Dado retirado do estudo realizado pela pesquisadora, "As culturas do Reinado Mineiro: o processo de aprendizagem e a transmissão de saberes". Dissertação de Mestrado. Programa de Pós-Graduação em Educação, Cultura e Organizações Sociais. Fundação Educacional de Divinópolis - UEMG, 2009.
}

licere, Belo Horizonte, v.24, n.1, mar/2021. 
Outra dança que acontece espontaneamente é a Dança da Jaca. Os corpos que conduzem os Dourados dançam em compasso binário e no contratempo do segundo tempo chocam os Dourados um ao outro, ao mesmo tempo em que saltitam. A Dança da Jaca é realizada em um movimento circular em que os Palhaços dançam girando, um de frente para o outro, tendo os pés como apoio e marcação. Esta dança acompanha a pulsação da música e seu objetivo dançar girando, tendo o Dourado como marcação da dança.

Os pés marcam o tempo em colcheias, alternando entre pé direito e esquerdo, e ao mesmo tempo em que giram chocam seus Dourados, ora a parte superior e ora a parte inferior. O gesto de colisão dos Dourados vem acompanhado de sentido expressivo, ou seja, os dançarinos se revelam um para o outro quando demostram habilidade gestual e rítmica, através de um movimento artístico e criativo. A dança é uma forma de homenagear aquele que sai à rua para ver e vivenciar a Folia de Reis. Nas danças os dançarinos se reconhecem e se firmam no grupo como Pessoa/Folião/Palhaço.

A Dança da Jaca é realizada pelos palhaços dançarinos sem a necessidade de receber esmola. Como as outras danças, está se insere na Folia de Reis com muita graça, poesia em forma de movimento que enfeita e celebra o momento sagrado dos foliões e dos devotos. Mas, mesmo depois de dançar, espontaneamente, no término da dança, os palhaços se voltam para algum devoto, direcionando suas sacolas abertas, num gesto de angariar esmola.

\section{Imagem 5: Acervo Sônia Assis.}




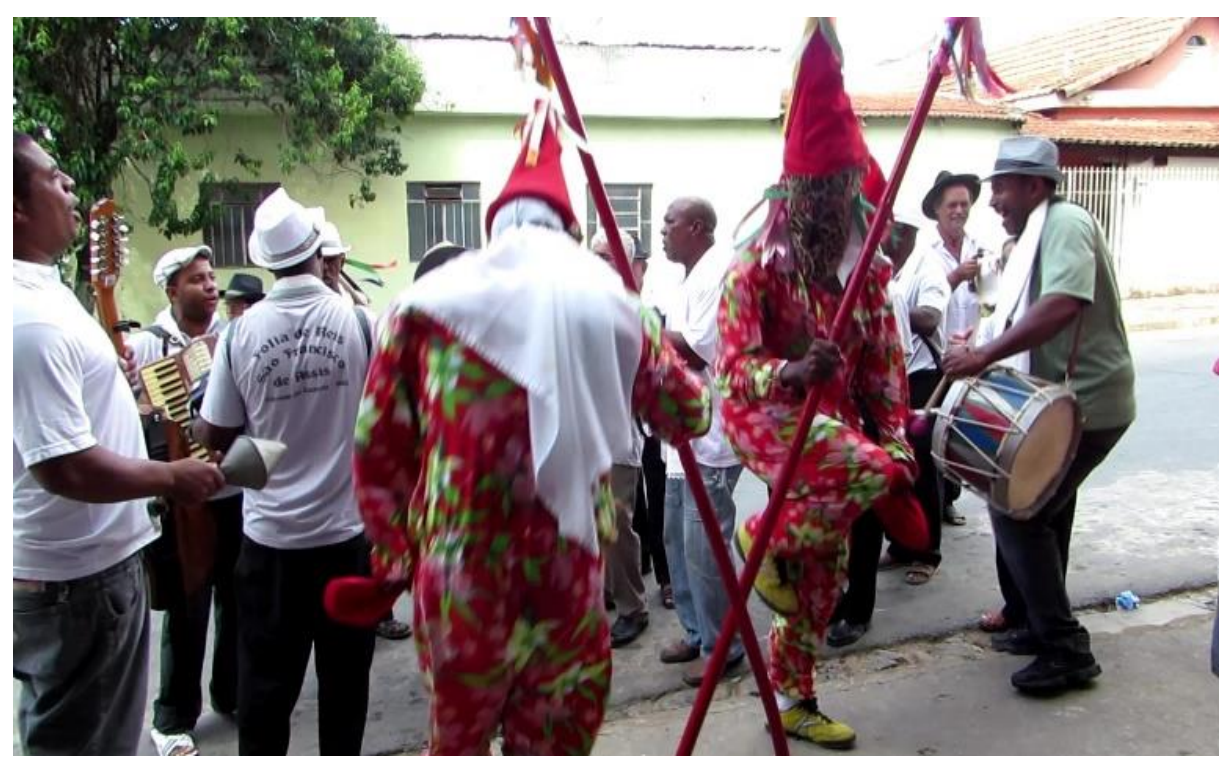

O som que sai do Dourado, as vozes fortes dos palhaços e suas brincadeiras preenchem, sonoramente, a performance musical da Folia de Reis. Desta forma, este mundo foi se mostrando para o estudo, pelos gestos em cada dança, pelos movimentos intencionais integrados de sons, corpos e instrumentos. Em um percurso expressivo, os gestos se conectam às frases musicais em um movimento de deslocamento espacial e temporal de um corpo físico a uma intenção expressiva.

Segundo Small (1999), a performance é um encontro, ajustado nas relações sociais que se estabelecem entre pessoas e coisas, que dela participam passivamente ou ativamente. Small emprega o termo "musicar" 16 em atuações musicais em que são tecidas diversas relações. Para ele, musicar engloba qualquer forma de engajamento com música, que vai desde a escuta até ao fazer musical. Assim, na festa da Folia de Reis, as relações existentes entre foliões e devotos é o que promove o ato de musicar.

\begin{abstract}
Musicar é tomar parte, de qualquer maneira, em uma atuação musical. Isso significa não apenas tocar ou cantar, mas também escutar, proporcionar material para tocar ou cantar: o que chamamos compor; preparar-se para atuar; praticar e ensaiar; ou qualquer outra atividade que possa afetar a natureza desse encontro humano que chamamos uma atuação musical. Desde logo podemos incluir o dançar, se alguém está dançando, e podemos também
\end{abstract}

\footnotetext{
${ }^{16} \mathrm{O}$ termo criado por Small é, também, utilizado em inglês como "musicking" e português "musicando" (Small, 1999).
}

licere, Belo Horizonte, v.24, n.1, mar/2021. 
ampliar o significado, até incluir o que faz a pessoa que recolhe as entradas na porta, ou os "roadies" que montam os instrumentos e checam a equipe de som, ou também os faxineiros que limpam a sala depois da atuação. Porque eles, e elas, também estão contribuindo para a natureza do acontecimento que é uma atuação musical (SMALL, 1999, p.5, tradução minha).

Musicar é a soma de todas as atividade que totalizam o evento. E o elo é a presença dos palhaços, sua movimentação e atitude. Um dos papeis do Palhaço, em meio às danças, perpassa em integrar devotos ao movimento da jornada para, assim, musicarem com e na Folia de Reis.

\section{Considerações}

Chego nas considerações deste artigo, justamente, no mês que as Folias de Reis saem às ruas em jornada. A pandemia, que nos privou de muitos encontros, não permitiu que as festas de Reisado e Reinado acontecessem no ano de 2020, que a paisagem da rua se transformasse com os coloridos das vestes dos palhaços, que os devotos pedissem danças e cantos, que os sons das caixas e dos cantos inundassem o ambiente anunciando a boa nova e a alegria festiva. Nem por isso podemos perder a esperança de reencontrar com as Folias de Reis com a humanidade imunizada do coronavírus e de todo o tipo de terraplanismo. Quando isso acontecer, lá estarei me revigorando como povo brasileiro, na cultura brasileira, na arte, na diversidade e no jeito de ser e viver. Foi no entrelaçamento das pessoas com os objetos sonoros, na medida em que ambos dialogavam, que me reencontrei. Segui os foliões agindo nos instrumentos sonoros e senti a sonoridade e musicalidade dando vida à festa. Nesta sintonia, não percebia quem ou o que estava atuando, se eram as pessoas ou os instrumentos sonoros, pois ambos se revelavam um para o outro numa performance mútua. Pessoas e instrumentos se relacionando e os papéis sendo constituídos pela experiência, pela história de vida e percurso. 
No entrelaçamento de pessoas e coisas, vivendo plenamente o ambiente da festa, compreendi como cada folião (embaixador, palhaço, folião, músico e devoto) se constituem como pessoa. Para se tornar embaixador não envolve somente saber cantar, mas "tirar de ouvido" os versos sagrados nos momentos apropriados, conduzir a Folia de Reis, envolver-se com o ambiente, com as pessoas, com os instrumentos e com a música. A cada encontro entre folião e devoto, os ritos e os versos ganham forma e sentido na participação ativa dos envolvidos. Crianças e adultos compreendem os rituais da Folia de Reis ao vivenciá-la por inteiro.

A performance dos Palhaços, o canto forte e suas brincadeiras preenchem a Folia de Reis São Francisco de Assis. Humanos e não-humanos foram se mostrando para a pesquisa pelos gestos em cada dança, pelos sons, pelos corpos e pelas cores. Em um percurso expressivo os gestos se conectavam às frases musicais, ou em um movimento de deslocamento espacial e temporal. Ser integrante ativo e participativo da Folia de Reis, constitui-se em experiências que dão condições de desenvolver habilidades dentro dos papéis que lhe cabe executar. A habilidade técnica, expressa nas danças, nos cantos e nos improvisos, é que os possibilitam vestir-se Palhaço, mascarar-se e movimentar-se com seu Dourado em diálogo com o ambiente, com a música e com as pessoas.

$\mathrm{O}$ acordeon é tido como o primeiro instrumento guia, e a caixa o segundo. $\mathrm{O}$ acordeon pela sonoridade potente que conduz a melódica. E as caixas por determinar o andamento da música. A introdução melódica feita avisa aos foliões o que está por vir e auxilia o embaixador a entrar na tonalidade certa. Assim, após escutá-la é que os outros instrumentos da folia se juntam ao acordeon. Como narra o embaixador, "A sanfona puxa e os outros instrumentos vão atrás, como o cavaco que tem que estar afinado com o acordeon". Desta forma, o acordeon direcionando a folia pela música, dando entradas, saídas, tom, mediando e equilibrando todo o fazer musical. 


\begin{abstract}
Diário de campo: Como fechamento, nos despedimos debaixo de uma chuva fria de uma noite de verão. O canto do embaixador, desde a entrada da casa até a saudação ao presépio, durou em média 30 minutos. Ele cantou histórias que narravam a vida do menino Jesus, homenageou o dono e dona da casa, adorou os Reis do Oriente e a Santíssima Trindade. Durante todo o ritual, os foliões cantaram, dançaram e tocaram, aliando a fé, o festejar, a oração coletiva, o riso e a brincadeira em um momento único de alegria de quem recebe graças e as agradece. Entendo que a noção de Festa é um mergulho na experiência do ritual, nos ritos, nas brincadeiras, nas danças ou nos cantos. Isto me permite dizer na mesma profundidade sobre o Lazer, que tem como sentido o encontro com o Outro, com as coisas, com a experiência e histórias de vida.
\end{abstract}

\title{
REFERÊNCIAS
}

BAKHTIN, Mikail. A cultura popular na Idade Média e no Renascimento: o contexto de François Rabelais. São Paulo: Hucitec; Brasília: Editora da Universidade de Brasília, 1999.

BALANDIER, Georges. A desordem: elogio do movimento. Rio de Janeiro: Bertrand Brasil, 1997.

BESSE, Jean-Marc. Entre a geografia e a ética: a paisagem e a questão do bem-estar. Trad. Eliane Kuvasney e Mônica Balestrin Nunes. GEOUSP - Espaço e Tempo (Online) São Paulo, v. 18 n. 2 p. 241-252, 2014. Disponível em: http://www.revistas.usp.br/geousp/article/view/84455. Acesso em: 17 jul. 2015.

GOMES, Christianne L.; ELIZALDE, Rodrigo. Horizontes latino-americanos do lazer/Horizontes latinoamericanos Del ocio. Christianne Luce Gomes, 2012.

INGOLD, Tim. A evolução da sociedade. In: FABIAN, A. C. (org.). Evolução: sociedade, ciência e universo. Bauru: Edusc, 2003. p. 107-131.

Da transmissão de representações à educação da atenção. Educação em revista. Porto Alegre, v. 33, n. 1, p. 6-25, jan./abr. 2010.

Trazendo as Coisas de Volta à Vida: Emaranhados Criativos num Mundo de Materiais. Horizontes Antropológicos, Porto Alegre, ano 18, n. 37: 25-44, jan./jun. 2012. Vozes, 2015.

Estar Vivo: Ensaios sobre movimento, conhecimentos e descrição. Petrópolis:

LUCE, Patrícia Campos; DEBORTOLI, José Alfredo Oliveira; GOMES, Ana Maria Rabelo. Experiência, performance e práticas de aprendizagem: temas para pensar o lazer de forma não fragmentada. Licere, v. 13, n. 2, 2010. DOI: http://doi.org/10.35699/1981-3171.2010.817

LUCAS, Glaura. Os sons do Rosário: o congado mineiro dos Arturos e Jatobá. Belo Horizonte: Editora UFMG, 2002. 
MAUSS, Marcel. As técnicas do corpo. Sociologia e antropologia. São Paulo: Editora Cosac \&Naify, p. 399-424, 2003.

MERLEAU-PONTY, Maurice. Conversas. São Paulo: Livraria Martins Fontes Editora Ltda, 2004.

2015.

Fenomenologia da percepção. São Paulo: Editora WMF Martins Fontes.

MERRIAM, Alan. P. The anthropology of music. Evanston: Northwestern University Press.1964.

SEEGER, Anthony. Etnografia da música. Cadernos de Campo. São Paulo, v. 17, n. 17, p. 237-260, 2008.

SMALL, Christopher. Musica, sociedad, educacion. Madrid: Alianza Editorial, 1999.

STRATHERN, Marilyn. O Gênero da Dádiva: problemas com mulheres e problemas com a sociedade na Melanésia. São Paulo: Editora da Unicamp, 2006.

O efeito etnográfico. Editora Cosac Naify, São Paulo, 2014.

\section{Endereço da Autora:}

Sônia Cristina de Assis

Rua Laudelina Carneiro, nº 857 - Enseada das Garças

Belo Horizonte - MG - 31370-260

Endereço Eletrônico: assis.soniacris@gmail.com 